\title{
Bruksområder for kardialt troponin
}

\section{Ny bruk av troponinmålinger kan forbedre diagnostikk og risikovurde- ring av hjerteinfarktpasienter og gjør det mulig å karakterisere hjerte- skade hos langt flere enn før.}

Troponin som biomarkør ved hjerteinfarkt er i stadig utvikling, men man har i senere tid også vist at markøren gir verdifull informasjon ved andre diagnoser. Mitt doktorgradsarbeid består av tre studier der hovedmålet har vært å undersøke nye aspekter av troponin ved hjerteinfarkt og obstruktiv søvnapné.

I den første studien sammenlignet vi pasienter som hadde fătt diagnosen hjerteinfarkt uten ST-elevasjon på EKG før og etter innføringen av høysensitiv troponinanalyseteknikk. Studien avdekket en kraftig økning i antall diagnoser etter at den nye testen ble benyttet. Selv om enkelte observasjoner antydet en mulig overestimering, understøtter funnene verdien av den nye testen.

I den andre studien ble troponinmålinger undersøkt som prognostisk verktøy hos 1066 pasienter med ST-elevasjonsinfarkt. Én enkelt blodprøve ga viktig informasjon om

\section{Ny blodprøve kan forenkle diagnostikk av cøliaki}

\section{$\AA$ A bestemme antall og type glutenreaktive T-celler i blod kan bli nyttig ved mistanke om cøliaki.}

Cøliaki skyldes en T-celledrevet intoleranse mot gluten og rammer $1-2 \%$ av befolkningen. Glutenfri kost er eneste tilgjengelige behandling. Diagnostiseringen kan være vanskelig selv ved bruk av tynntarmsbiopsier, serologiske tester med høy spesifisitet og muligheter for HLA-typing (nesten alle pasientene er positive for HLA-DQ2 eller HLA-DQ8). Det skyldes blant annet at befolkningen i økende grad og på eget initiativ spiser glutenfritt. Ettersom glutenfri kost normaliserer de tilgjengelige diagnostiske parameterne, må pasienter før utredningen spise glutenholdig kost i minst fire uker. Det kan være svært utfordrende for glutensensitive personer.

I mitt doktorgradsarbeid har jeg brukt et reagens bestående av ulike glutenpeptider og HLA-DQ2-molekyler til å påvise glutenreaktive CD4+ T-celler. I blod fra friske individer fant vi at antall glutenreaktive T-celler var svært lavt og at de hadde en inaktiv fenotype. De hadde heller ikke fenotypen til regulatoriske T-celler, slik man kunne ha forventet ha forklart hvorfor de fleste individer ikke utvikler cøliaki. antall glutenreaktive T-celler med en fenotype som viste at de var aktivert. I tillegg glutenpeptid ofte samme T-cellereseptornoe vi ikke fant hos friske. til å diagnostisere cøliaki direkte, men det

Asbjørn Christophersen

asbchr@rr-research.no risiko for nedsatt hjertefunksjon samt alvorlige kliniske hendelser og død under oppfølgingstiden. Funnene støtter bruk av troponin for risikovurdering av slike pasienter.

I den tredje studien brukte vi en helt ny og svært sensitiv troponinanalyse som gjorde det mulig å beregne nivået hos 222 personer undersøkt for mulig obstruktiv søvnapné. Funnet bekrefter at troponinmålinger med mer presis og sensitiv analyseteknikk gjør det mulig å evaluere hjertets tilstand hos flere pasienter enn tidligere. Nytteverdien av troponin var begrenset for diagnostisk utredning av mulig obstruktiv søvnapné.

Troponinmålinger er viktig i den kliniske hverdagen, men kan potensielt ha enda flere bruksområder enn tidligere antatt.

Trygve Sørdahl Hall

trygvesh@gmail.com

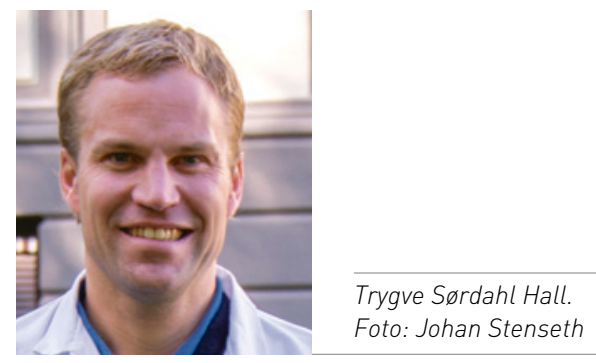

Disputas

Trygve Sørdahl Hall disputerte for ph.d.-graden ved Universitetet i Oslo 6.10. 2015. Tittelen på avhandlingen er Novel aspects of cardiovascular biomarkers in myocardial infarction and obstructive sleep apnea.

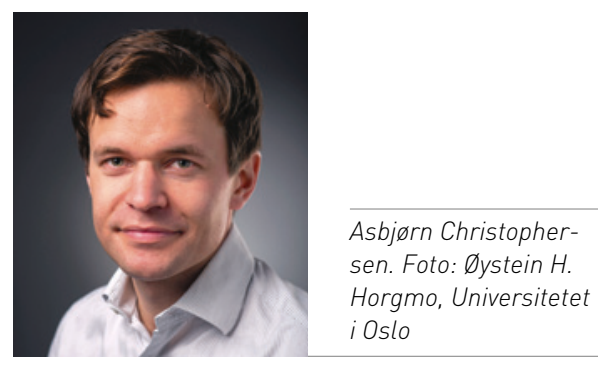

ut fra forutgående studier i mus og som kunne

I blod fra personer med cøliaki på glutenholdig og glutenfri kost fant vi et langt høyere hadde T-cellene med respons mot et spesifikt sekvens på tvers av individene med cøliaki,

Funnene indikerer at måling av glutenreaktive celler i blod kan brukes i utredningen av cøliaki. I første rekke kan man bruke metoden til å skille ut personer på glutenfri kost som man ønsker å gå videre med i utredningen av cøliaki. Metoden kan potensielt også brukes forutsetter flere og større studier. 